\title{
INDONESIA'S REGULATION AND POLICY IN THE ENERGY SECTOR: URGENCY TO PROMOTE ENERGY EFFICIENCY IN URBAN AREAS
}

\author{
Imam Mulyana; Achmad Gusman Siswandi \\ Faculty of Law, University of Padjadjaran \\ E-mail: imam.mulyana@unpad.ac.id; ahmad.gusman@unpad.ac.id
}

\begin{abstract}
In recent years, efforts to promote sustainable energy through energy efficiency, renewable energy and use of new technologies are moving rapidly at national, regional, and international levels. The benefits generated from energy efficiency has prompted experts and governments to work together in implementing energy efficiency policies across all sectors of life. One of the focus areas in global energy efficiency policy is energy efficiency in urban areas. This article aims to provide an overview regarding the implementation of policy and regulation on energy efficiency in Indonesia, particularly in urban areas. The research finds that energy efficiency is one of the most effective ways to improve the competitiveness and capacity of cities in Indonesia. In addition, it could advocate the Indonesian Government in responding to global environmental issues, especially climate change.
\end{abstract}

Keywords: sustainable energy, efficiency, urban areas

\section{A. INTRODUCTION}

Energy is one of the important elements in supporting the life of mankind. Energy plays an important role in linking economic growth, social justice, and decent environmental conditions (United Nation, 2012 : 3). Energy has also been considered as a pivotal element in the process of development. This fact has been confirmed more than a century ago, as Soddy observed (Soddy, $2007: 1$ )

"No one today is ignorant of the part played by energy, not only in science, but in industry, politics, and the whole science of human welfare. From the cradle to the grave, everyone is dependent on nature for an absolutely continuous supply of energy in one or other of its numerous forms. When the supplies are ample, there is prosperity, expansion, and development. When they are not, there is want."

In this regard, the World Bank has defined basic needs that should be enjoyed by every human being, i.e. food, water, shelter, health, education, and employment. Among these basic needs, energy is not explicitly mentioned, however it would not be possible to enjoy all of these basic needs without energy (Read Imam Mulyana, 2016 : 38-60). 
Today, energy has become an important subject related to sustainable development (Oxford University, 1987 : 43), a concept which has evolved as one of the main principles in international law, particularly in the field of environmental law. Sustainable development embodies three essential pillars: social, economy, and environment. It has been elaborated in many areas of economic development, for instance the Blue Economy (Achmad Gusman Siswandi, 2013 : 483).

The linkage between these three pillars is also reflected in the field of energy. For instance, according to the World Energy Assessment Report there are two important issues related to energy consumption and production in the context of sustainable development. Firstly, the adequacy of energy services in meeting basic needs, improving social welfare, and achieving economic growth. Secondly, the energy consumption and production must not endanger the quality of life for today and future generations, and also should not exceed the carrying capacity of the ecosystem (United Nations, $2000: 11)$.

Furthermore, the World Energy Assessment proposes multiple recommendations that should be considered by countries as a concrete step in the utilization of energy in line with sustainable development. These include (United Nations, $2000: 12$ ):

1. Implementing energy efficiency, especially in energy consumption in buildings, electrical equipment, motor vehicles and industrial production processes;

2. Increasing the use of renewable energy sources; and

3. Encouraging the use of new energy technologies, particularly the next generation of fossil fuel technologies. In this regard, nuclear technology can also be considered once environmental issues relating to nuclear energy are resolved.

Based on these recommendations, efforts to encourage sustainable energy consumption through energy efficiency, renewables, and new technologies continue to be pursued in national, regional, and international levels. In this regard, the role of law is essential in ensuring the organization as well as the harmonization of rules and policies related to energy utilization (Rosemary Lyster, 2006 : 11).

Global awareness towards energy efficiency has gained increasing support, especially after the United Nations adopted the 17 Sustainable Development Goals (SDGs) in 2015. Goals related to energy are particularly addressed under Goal 7 and Goal 12. Goal 7 aims to double the global rate of improvement in energy efficiency by 
2030 (http://www.un.org/sustainabledevelopment/sustainable-consumption-production, diakses tanggal 13 Januari 2018). Goal 12 confirms that household consumes $29 \%$ of energy from the total of world energy, and contributes $21 \%$ of carbon dioxide gas emissions. This therefore reflects energy efficiency as one of the main agendas of SDGs.

There are a number of models and regulations today that can be used as references in designing energy efficiency policy (UNEP, 2007 : 5). In general, the regulatory models in the form of recommendations have been issued by a number of international organizations, such as the United Nations Environment Programme (UNEP), the World Bank and the International Energy Agency (IEA). Some of these recommendations have been focused on the development of energy efficiency policy in urban areas.

Urban areas are estimated to have taken two-thirds of the total world energy consumption. This figure is expected to increase in 2030 to three-quarters of total world energy consumption in line with urbanization in developing countries (ESMAP, 2014 : 3 ). In 2030 , it is estimated that 4.9 billion people (60\% of the world population) will inhabit urban areas and consume $73 \%$ of total world energy, while approximately $76 \%$ of the emission of exhaust gases will be produced from urban areas, and $81 \%$ of new urban areas will grow in developing countries.

In terms of investments, according to IEA, investment in energy efficiency since 1990 has almost reached 5.7 billion USD. However, the benefits of energy efficiency far exceed the number of digits that have been invested, especially with respect to energy security, increased productivity in the industry sector, and the reduction of greenhouse gas emission. An estimated $40 \%$ reduction in exhaust emissions of greenhouse gases that is needed in the year of 2050 to restrict global temperature rise no $\begin{array}{lll}\text { more } & { }^{\circ} \mathrm{C}\end{array}$ (http://www.unep.org/pdf/ccScienceCompendium2009/cc_ScienceCompendium2009_f ull_en.pdf, diakses tanggal 14 Maret 2015) is potentially contributed by energy efficiency sector (http://www.iea.org/publications/freepublications/publication/energyefficiency-market-report-2015-.html, diakses 22 April 2016). Realizing global benefits of energy efficiency, experts and governments have been working together in diversifying and implementing energy efficiency policy in all sectors of life. 
Pursuant to the global trend in energy efficiency policies, Indonesia is also required to participate and plays an important role in order to make the policy a success. A number of commitments have been made at national level as well as at regional level. Within the context of the Association of South East Asian Nations (ASEAN), Indonesia has a strong commitment to lower its energy intensity by one percent each year until 2025 (http://www.iea.org/publications/html, diakses tanggal 20 April 2016).

At the domestic level, Indonesia has adopted a number of policies and regulations associated with energy efficiency, specifically in the Government Regulation Number 70 the Year 2009 on Energy Conservation (Peraturan Pemerintah Nomor 70 Tahun 2009). Although Peraturan Pemerintah Nomor 70 Tahun 2009 has regulated certain issues about energy efficiency, this regulation is considered too general and has not fully described strategic steps in promoting energy efficiency. Consequently, it has raised a number of deficiencies, such as limited scope of activities and lack of directive for local government to implement this regulation. Another problem associated with energy conservation is the heterogeneous nature of urban area condition in Indonesia. This condition therefore requires a particular approach and needs to embrace divergent rather than convergent regulations and policies, especially at the local government level.

\section{B. PROBLEM STATEMENT}

This research aims to, firstly, find out the essential elements that need to be considered in formulating regulations and policies with respect to energy efficiency in urban areas in Indonesia. Secondly, it aims to analyze problems and challenges in implementing such regulations and policies.

\section{RESEARCH METHOD}

This research will apply a normative approach by analyzing relevant international conventions, laws and other legal documents, as well as the results of research, assessment, and other references related to energy law, especially energy efficiency in urban areas. This research is also complemented by a comparative study to examine practices with respect to energy efficiency regulations and policies that are implemented at regional and international levels. 


\section{DISCUSSION AND RESEARCH S}

\section{Global Crisis in Energy and Why It Matters to Indonesia}

Energy crisis, urbanization, and climate change are three global challenges of the twenty-first century. They are closely interrelated either by causal effect (where one causes the other) or by three separate phenomena that have parallel impacts.

Initial international attention to the links between urbanization, environmental quality, and poverty during the 1970s focused on the need for human settlements to provide adequate shelter, sanitation, and local environmental quality, rather than on the potential wider impacts of urbanization. With the publication of the 1987 Brundtland Report, and its crystallization of the concept of sustainable development, the remit of cities in addressing environmental issues was recast as central to the new agenda. Chapter 9, 'The urban challenge', argued that as the majority of the world's future population will live in urban areas, cities should be central to the pursuit of sustainable development. The focus of the report on the integration of economic, social, and environmental concerns, together with global and local issues, made cities a key arena in which the concept of sustainable development could be applied. This role was reinforced at the 1992 United Nations Conference on Sustainable Development in Rio de Janeiro, with the call for all local authorities in partnership with stakeholders and their communities to produce Local Agenda 21 (LA21), through which sustainable development is addressed. LA21 has since "precipitated extensive action at the level of the municipality' world-wide. Simultaneously, initiatives such as the 1990 Green Paper on the Urban Environment, the adoption in 1998 of Sustainable Urban Development in the European Union: A Framework for Action, and the 2004 communication Towards a Thematic Strategy on the Urban Environment (Commission of the European Communities, 2004), have promoted urban sustainability within the European Union (EU) (Harriet Bulkeley, 2005 : 42-43).

As stated in the Intergovernmental Panel on Climate Change (IPCC), a scientific body under the auspices of the United Nations, humanity has the potential to affect global climate change. The onset of industrialization and the consumption of fossil fuels enabled human activities to substantially alter the global atmosphere via the emission of GHGs. As a result, atmospheric levels of GHGs have greatly increased, with carbon 
dioxide at 40 percent and methane at 140 percent higher level than existed prior to the onset of industrialization (See Roy Andrew Partain, 2016 : 302-325).

The primary causes of the climate change is carbon emission. These phenomena called 'anthropogenic climate change', which is highly associated with carbon emission. There is a linear relationship, emit more carbon, surface temperature increase. The dominant sources of carbonaceous emission are the combustion events of conventional of conventional fossil fuel products such as coal, crude oil, and natural gas. Conservative scientific consensus indicates that in order to maintain a 50 percent chance of averting catastrophic climate change, the global temperature must not increase by more than $2^{\circ} \mathrm{C}$ by 2050 . To achieve this in the most cost-effective manner, GHG emissions must peak between 2017-20 and then rapidly decline. But currently, the world is 'nowhere near' a 'realistic path' to globally decarbonise all energy generation by 2050 . So significant are these challenges that an urgent 'energy revolution' is required, 'before the door to $2^{\circ} \mathrm{C}$ is closed' (International energy Agency, 2011 : -).

In the area of urbanization, the year 2007 marked a watershed in human history, for the first time more people lived in cities than in the countryside (GlobeScan and MRC McLean Hanzel, 2007 : 1). It is estimated that by the middle of the century, $70 \%$ of the world's population will reside in cities (UN HABITAT, 2012 : -). This rapid urbanization is especially evident in the cities of the developing world where more than $70 \%$ of the world's urban population currently lives (UN HABITAT, 2016 : -).

Over the past 50 years, cities have expanded into the land around them at a rapid rate. Highways and transport systems have been built in tandem to support this physical growth. Valuable farmland has been eaten up, and car dependency has increased. Between 2010 and 2015, urban populations are expected to grow by around 200,000 people on average each day, with $91 \%$ of this daily increase expected to take place in developing countries. This increase is led by Asian and African cities (Heba Allah dan Essam E, 2015 : 2). Modern urban living crucially depends on uninterrupted energy supplies. The world's major transport systems start and end in cities.

Using energy more efficiently is one of the effective ways in order to promote the competitiveness and increase the capacity of a city to be more livable, and is one important way to respond to global issues, particularly climate change. Energy efficiency policy has also been proven to save government expenditure so that the 
government can re-allocate funds to other more important expenses. For example, the Municipality of Emfuleni in South Africa initiated an energy and water efficiency project that cost US\$ 1.8 million and achieved annual monetary savings of over US \$4 million. This initiative has enabled the municipality to pay back the initial investment in less than six months and generate a net cash-saving stream that will last for years (ESMAP, $2014: 3$ ). In fact, the benefits of investing in energy efficiency in cities go beyond immediate financial savings. For example, the City of Los Angeles spent US\$ 56.9 million to replace 140,000 of the city's streetlights with LED technology. The investment will not only provide an estimated US\$ 10 million in annual energy and maintenance cost savings; it will also enhance lighting quality, improve street safety, reduce light pollution, and cut local CO2 emissions by more than 40,000 tons each year.

In the Indonesian context, a historic transformation is currently undergoing from a rural to an urban economy. The country's cities are growing faster than in other Asian countries at a rate of $4.1 \%$ per year. By 2025 - in less than 10 years - Indonesia can expect to have $68 \%$ of its population living in cities. Indonesia has the third-largest amount of urban land in East Asia, after China and Japan. Between 2000 and 2010, the amount of urban land in Indonesia increased from about 8,900 square kilometers to 10,000 , or $1.1 \%$ each year. It is the largest increase in the absolute amount of urban land after China (http://www.worldbank.org/en/news/feature/2016/06/14/indonesia-urbanstory, diakses bulan Desember 2017).

Indonesian cities are not spending well or enough on its infrastructure. The country's economy grew by an average of $5.8 \%$ in the mid to late 2000 s, but infrastructure stock grew by only $3 \%$. In contrast, China invested $10 \%$ of GDP in its infrastructure over the past decade. Insufficient investments in infrastructure leave many communities vulnerable to poverty. Only $48 \%$ of households now have access to safe water, compared to $50 \%$ more than a decade ago. Sewerage coverage exists in only 11 of the country's 98 cities. Only $2 \%$ of city residents have access to centralized sanitation systems. High population density can put more pressure on existing infrastructure. From 2000 to 2010, urban population density in Indonesia increased sharply, from 7,400 people per square kilometers to 9,400 people. The amount of new urban land added per new resident is less than 40 square meters, the smallest amount of any country in the region. 
Energy efficiency in Indonesia is closely linked to the National Energy Policy which aims to pursue the security of domestic energy supply. The targets until 2025 for energy conservation is to achieve energy elasticity become less than 1 . The intention of this policy is to promote significant increase in usage energy efficiency compared with the current condition, which described that energy elasticity still above the target. Furthermore, it means that energy consumption is wasteful. In addition, the policy targeted that energy intensity will be dropping by 1 percent annually until the year 2025 (Endang Lestari, $2011: 31$ ).

The pattern of energy consumption in Indonesia is still not efficient because it has not been supported by electronic equipment standards and people's behaviour as energy consumers. This condition is reflected from three largest segments of electrical energy users namely industry, commercial (buildings and malls, offices), and households.

For based energy-intensive industries such as steel, cement, ceramics, glass and textile industries, Indonesia's energy intensity is still above other countries such as India, Vietnam, Korea and Japan. Even though there several legal documents related to energy conservation but their implementation is still not optimal yet. From energy audit results in 127 industries, energy savings are estimated at 486,880,500 kWh/year while in 24 office buildings, energy savings are estimated at $92.301 .255 \mathrm{kWh} / \mathrm{year}$. In the household sector, electricity sales increase is estimated to be $6 \%$ per year and the average electricity sales are estimated to be 53,645,311.6 MWh/year. If it is assumed in the household sector to save 5 percent (i.e. housekeeping or savings without investment), then the savings can be estimated at 2,682,265.6 MWh.

As a party to the United Nations Framework Convention on Climate Change (UNFCCC) Indonesia has a strong commitment, not just in international but also in regional (ASEAN) level to give best effort to promote energy efficiency, especially in urban areas. To make energy efficiency a success, urban areas in Indonesia must maintain the balance between social, economic and environmental needs, so it would be able to respond the pressure from all sides. It should offer investors security, infrastructure (including water and energy) and efficiency. It should also put the needs of its citizens at the forefront of all its planning activities. From the explanation above, what emerges is a mainly positive view of energy efficiency. Its can bring multiple benefits in the environmental, social, and economic spheres. Therefore, the government 
of Indonesia should give more concern to the development of the energy efficiency sector.

\section{The Development Energy Efficiency Policies and Potential Obstacles}

In an attempt to mobilize international cooperation on clean energy reform and uptake, the United Nations General Assembly ('UNGA') declared the year of 2012 as the International Year of Sustainable Energy for All. Empowered by this resolution, United Nations Secretary-General ('UNSG') Ban Ki-moon set out the following global Sustainable Energy for All ('SEALL') challenges for 2030 (UNSG Report, 2011 : -):

(i) Universal access to energy services;

(ii) Doubling the rate of energy efficiency improvement; and

(iii) Doubling renewable energy in the global energy mix from 15 to 30 percent.

Furthermore, to actualize a successful energy efficiency legislation, it requires three levels of governance: international law, national law, and local law. The first level can initially take the form of international treaties. The key of a source of energy law and policy is national governments. Governments set the energy policy in their countries and then introduce the legislation to meet those goals. The final place where energy law and policy is developed is at a local level. This is where local legislators from regions to small countries (or districts) set certain energy goals and may offer local incentives for companies that plan to develop energy infrastructure in their region (Raphael J. Heffron, 2015 : 4-5).

The European Union has been acknowledged as the most advanced regional energy efficiency initiative, especially in urban areas. This condition cannot be separated from the development of regional provisions promoted by the European Union. One of the most important regulations related to the energy efficiency policy on an urban area is the Energy Efficiency Directive 2012/27/EU (EED), which binds all member states to energy efficiency. EED replaces the previous two regulations, Directives 2004/8/EC on cogeneration and Directives 2006/32/EC on energy services. EDC also deals with the obligations set forth in Directive 2009/125/EC on Eco-design, Directive 2010/30/EU on energy labelling and Directive 2010/31/EU on the energy performance of buildings. EDC begins to effectively bind in December 2012 and 
member countries are required to realize the obligations in the EDC starting from June 2014 (Framework Report, 2015 : 7).

The arrangements in EEDs related to urban energy efficiency begin from the opening section number 18, requiring mayors to encourage energy efficiency in their respective cities. Other provisions in EED related to energy efficiency in urban areas include (Framework Report, 2015 : 9):

1. In Article 4 on "Building Renovation", the city government is encouraged to develop a long-term strategy to mobilize investment in buildings for residential, offices, or other public and private buildings;

2. In Article 7 on "Obligations of energy and alternative energy", it is explained that all member countries should submit policy plans to the European energy commission on December 5, 2013, detailing detailed plans, detailed proposals on operating schemes and methods for achieving targets, including having to explain the set of policies taken in order to realize the policy; and

3. Under article 24 on "review and monitoring implementation", member countries are required to publish a long-term plan on building renovations related to energy efficiency in urban areas on April 30, 2014.

The policy implementation in energy efficiency in some countries generally starts from establishing the minimum standards that must be fulfilled. The establishment of minimum standards is also considered more flexible for governments to encourage efforts to improve energy efficiency while providing some allowances for stakeholders to make adjustments, not only in technological adjustments but also in financial adjustments. With proper evaluation and monitoring mechanism, a government can raise the minimum standards gradually so the energy efficiency achievements continuously increase. In general, regulations and policies to improve efficiency in urban areas are directed into four main sectors (Victor Anderson, 1993 : -) energy consumption; building arrangements; land use; and transportation.

Over the years, governments at all level have developed policies to overcome the barriers to energy efficiency. The theory is simple: barriers can be overcome with the design and implementation of targeted energy efficiency policies. Energy efficiency laws or decrees are important because they can give direction to energy efficiency policies, provide a statutory basis for rules and regulations, assign responsibility for 
developing rules or implementing programmes, and specify funding required and funding mechanism for energy efficiency activities (OECD, $2010: 14$ ).

Energy efficiency policies have also influenced a number of energy policies changes at a national level in some countries around the world. There are several evidence which describe that energy efficiency has been considered as a primary target to achieve in the energy sector. For example (Raphael J. Heffron, 2015 : 9) :

1. Angela Merkel's government in 2005 amended energy policy in Germany. The energy policy promoted by her government put a significant emphasis on renewable energy development and the closure of nuclear energy plants - which did receive an impetus after the Fukushima accident in Japan in 2001;

2. The indecision of the UK coalition government elected in May 2010 has delayed new investment in UK energy sector. It took the first few years of the government for the Conservatives and the Liberal Democrats parties to agree with a way forward. The indecision has reduced the interest from investors in the UK energy sector, and there has been little interest in developing energy infrastructure;

3. Since the election of Francois Hollande as president of France in May 2012, France energy policy has changed. The previous dominance of nuclear energy within the French energy policy is being reduced and a new emphasis has been placed on renewable energy development, with a planned limit on the use of nuclear energy to $50 \%$ of the countries energy's mix by 2025 .

In order to achieve effective energy efficiency legislation, legal drafter or policymakers should be able to combine elements of legal certainty in a legislation, the rate of energy consumption, and technological changes. Energy efficiency legislation should contain the following key elements:

1. Describing the government's objectives and intentions in implementing energy efficiency;

2. Aiming specific targets, numbers, and goals;

3. Providing justification if the government needs to intervene;

4. Organizing responsibilities for planning and implementation;

5. Governing the provision of funds and resources; and 
6. Providing monitoring and evaluation mechanisms.

Based on the research in IEA member countries, energy efficiency is the most popular policy particularly from financial point of view. Nevertheless, the IEA also notes that the success or failure of a policy in the field of efficiency in a country is also very dependent on how the government expertly combines a number of existing policies. For example, the energy efficiency policy in some cases requires substantial financial support but the benefits are not immediately available. So, in this case, a number of financial policies such as incentives, tax arrangements or borrowed funds must also be integrated so that policies can run. Making policy in the energy sector especially encouraging energy efficiency is deal with varying complexity. However, from experience, IEA gives the following conclusions:

1. Creating an energy efficiency policy based on a mixture of policies is the best option compared to just a single policy instrument. This is because energy is consumed in various ways by various consumers. In some cases, these policies will reinforce each other's effectiveness.

2. Encouraging policies in all sectors of energy are more effective and directly impacts rather than focusing or prioritizing on a single policy. For example, the increased efficiency of fuel usage by vehicles is not only due to the reduced number of vehicles but also to public transportation, the population, even the development strategy of the region.

Indeed, drafting the energy efficiency policy is not a simple task. Decision makers need to address other challenges in developing effective energy efficiency legislative programmes, among others:

1. Comprehensive vs incremental laws. There is a trade-off between a comprehensive law that takes years to develop and enact, and narrowly focused law that can be quickly enacted but will have limited impact. Which approach that is most suitable will vary from country to country, according to both technical and political considerations.

2. Soft law vs hard law. Governments need to decide whether want to pursue a "soft" energy efficiency law (that provides only principles and intentions) or 
"hard" energy efficiency (that provides the statutory basis and funding authorizations needed for actual implementation).

3. Avoiding implementation delays. Enacting an energy efficiency is usually only the first step, as many details required for implementation (establishing new agencies, building technical capacity, promulgating regulations, developing standards, establishing reporting protocols, administrative details of incentive mechanism, etc.) will still need development. In some countries, this additional detail is provided through "secondary laws" which promulgate specific procedures and regulations. Implementation delays can be avoided by building capacity in rule-making and programme administration ahead of law's passage, and by devoting attention to stakeholder engagement. For example, in Singapore, capacity development of auditors and energy manager is being undertaken well ahead of the expected 2012 enactment of the country's Energy Conservation Law (ECL).

4. Need for revisions and amendments. The relevance of energy efficiency laws and decrees will change over time. Increased flexibility can be obtained through rules and regulations governing a whole set of products rather than one specific technology or devise.

5. Balancing the conflicting interest of different government departments. The formulation of energy efficiency laws involves a compromise between conflicting interests in the public and private sector, as well as within different government agencies. Creating consensus and balancing intra-governmental conflicts will depend on the country context and the relative role of parliamentarians, government bureaucrats, interest groups and civil society.

Furthermore, although not as advanced as European countries, the energy efficiency policy in Indonesia has developed significantly in order to reduce emissions that are incredibly harmful to the environment. In 2009, Indonesia voluntarily pledged to reduce emissions by $26 \%$ on its own efforts, and up to $41 \%$ with international support, against the business as usual scenario by 2020. Indonesia has promulgated relevant legal policy and instruments, including the national action plan on GHG emissions reduction as stipulated in Presidential Regulations (PERPRES) Number 61/2011 and GHG inventory through Presidential Regulations Number 71/2011. 
Beyond 2020, Indonesia envisions an even bolder commitment to emission reductions. In the energy sector, Indonesia has embarked on a mixed energy use policy, with at least $23 \%$ coming from new and renewable energy by 2025. Indonesia has also established the development of clean energy sources as a national policy directive. Collectively, these policies will put Indonesia on the path to de-carbonization.

Indonesia's National Master Plan for Energy Conservation (RIKEN) sets a goal of decreasing energy intensity by $1 \%$ annually until 2025 . In order to reach this goal, energy savings potentials have been identified as follows: industry (15-30\%), commercial buildings (25\%), and households (10-30\%). Once these potentials were established, a plan was formulated to achieve them; the plan includes fiscal incentives (tax deductions and soft loans) together with other instruments such as training and educational programs as well as energy audits.

However, the Indonesian National Energy Policy also foresees the share of coal to be $30 \%$ by 2025 and $25 \%$ by 2050 , and Indonesia is also working on the construction of new coal-fired power plants to meet rapidly increasing electricity demand, a development likely to bind the country to this carbon-intensive technology for many decades. Various other sources also predict that coal will keep playing a major role in Indonesia's energy mix in the foreseeable future. An installed capacity of $25 \mathrm{GW}$ of coal-fired power plants will emit roughly $200 \mathrm{MtCO}_{2} \mathrm{e} / \mathrm{a}$. Unless the coal plants are decommissioned before the end of their lifetime, they will continue to emit this amount over the next 50 years. These developments in energy policy represent an apparent mismatch in the context of climate policy with, on the one hand, renewables being pushed to play a stronger role in the energy mix, but, on the other hand, locking in the role of coal (http://climateactiontracker.org/countries/indonesia.html, diakses tanggal 6 Januari 2015).

\section{E. CLOSSING}

Urbanization in Indonesia is expected to increase from year to year. People migration from rural to an urban area will cause various problems. One of the important issue to consider by the government is energy. The international community today has developed various policies in order to handle the global energy crisis. Various policies have expanded including conduct the research to find new energy resources through 
renewable energy and develop various policies associated with energy efficiency. The energy efficiency policy in urban areas is one of the best options to overcome the urbanization flows and it is also a strategic policy to ensure energy sustainability. This development has been generally anticipated by the Indonesian government, as reflected in the current policies and legal means of energy management. However, such policies and regulations are still very broad and still need to be developed more comprehensively, especially at the local level.

\section{Bibliography}

\section{Books:}

Foster REG, 2015, Energy efficiency in Urban, Regeneration Framework Report,.

ESMAP (Energy Sector Management Assistance Program), 2014, The World Bank, the City Energy Efficiency Assessments.

Heba Allah and Essam E. Khalil Energy, 2015, Efficiency in the Urban Environment. London: CRC Press, Taylor \& Francis Group.

Idris, et al.. (ed), 2013, The Role of Law in Development in Indonesia: Reality, Hope, and Challenge-Liber Amicorum Prof. Dr. Etty R. Agoes, SH, LL.M. Bandung : Remaja Rosdakarya.

International Energy Agency, 2011, World Energy Outlook 2011, OECD Publishing. OECD/IEA, 2010, Energy Efficiency Governance Handbook $2^{\text {nd }}$ edition.

Raphael J. Heffron, 2015, Energy Law: An Introduction, Springer: London UK.

Rosemary Lyster, Adrian Bradbrook, 2006, Energy Law and the Environment, Cambridge UK : Cambridge University Press the Edinburgh Building.

Roy Andrew Partain, 2016, "Climate change, green paradox models and international trade rules", in Panagiotis Delimatsis (ed.), UK : Research Handbook on Climate Change and Trade Law, Edward Elgar.

Sanam S. Haghihi, 2007, Energy Security, The External Legal Relations of the European Union with Major Oil-and Gas-Supplying Countries, Hart Publishing: Oxford and Portland Oregon.

International Energy Agency, 2015, Southeast Asia Energy Outlook 2015.

UNEP, 2007, UNEP Handbook for Drafting Laws on Energy Efficiency and Renewable Energy Resources. 
Victor Anderson, 1993, Energy Efficiency Policies, London and New York: Routledge.

\section{Journals:}

Harriet Bulkeley and Michele M. Betsill, "Rethinking Sustainable Cities: Multilevel Governance and the 'Urban' Politics of Climate Change'. Journal Environmental Politics, Taylor and Francis, Volume 14, 2005.

Imam Mulyana, "The Development of International Law, in the Field of Renewable Energy”, Hasanuddin Law Review Journal, Volume 2 Issue 1, April 2016.

\section{Laws and Regulations:}

Law Number 30 of 2007 on Energy.

Presidential Regulation (PERPRES) Number 5 of 2006 on National Energy Policy.

Presidential Regulations (PERPRES) Number 22 of 2017 on General National Energy Plan.

\section{Documents:}

Implementation of Agenda 21, the Programme for the Further Implementation of Agenda 21 and the Outcomes of the World Summit on Sustainable Development: Report of the Secretary-General, UN GAOR, 66th session, Agenda Item 19(a), UN Doc A/66/287 (9 August 2011) 5 [17] ('UNSG Report 2011').

Indonesia National Master Plan for Energy Conservation, 2014.

Intended Nationally Determined Contributions Indonesia 2017.

The Secretary General's High-Level Group on Sustainable Energy for All, the Sustainable Energy for All: A Global Action Agenda (United Nations, New York, 2012)

Transforming Our World: The 2030 Agenda for Sustainable Development, UN Doc A/RES/70/1, October 21, 2015.

United Nations Development Program, United Nations Department of Economic and Social Affairs and the World Energy Council, World Energy Assessment: Energy and the Challenge of Sustainability, United Nations, New York, 2000. 
United Nations General Assembly Declares 2014-24 Decade of Sustainable Energy for All' (Press Release, GA/11333 EN/274, 21 December 2012).

\section{Others:}

CP J. McMullen and Jabbour, Climate Change Science Compendium 2009.

Endang Lestari, Evaluasi Pelaksanaan Kebijakan Konservasi Energi, Majalah Mineral \& Energi, Vol. 9, Number 1, Maret 2011.

Sustainable Development Goals: 17 Goals to Transform Our World.

United Nations Human Settlement Programme (UN HABITAT), The State of the World's Cities Report 2012/2013: Prosperity of Cities, UN-HABITAT, Nairobi, Kenya.

United Nations Human Settlement Programme (UN HABITAT), The State of the World's Cities Report 2006/2007: 30 Years of Shaping the Habitat Agenda, Earthscan, London, UK.

\section{Website:}

http://www.esmap.org/node/3155

http://climateactiontracker.org/countries/indonesia.html

http://www.un-documents.net/our-common-future.pdf

http://www.iea.org/publications/html

http://www.worldbank.org/en/news/feature/2016/06/14/indonesia-urban-story 